\title{
COVID-19 and avian corona viruses: epidemiological comparison and genetic approach
}

\author{
Amine BERGHICHE \\ Laboratory of Science and Technique of the Living, University of Mohamed Cherif Messaâdia, Souk Ahras, Algeria \\ Corresponding author's Email: amine_berghiche@yahoo.com; a.berghiche@univ-soukahras.dz
}

\section{ABSTRACT}

Aim. This study aimed to collect and analyse available information on COVID-19 and avian corona viruses in order to conduct a systematic review of the genetic data concerning them. Methods. All available research was done according to the strictest data selection criteria, and the databases like NCBI genebank were quantitatively searched in the currently available scientific literature using keywords, analytical statistic and genomic software. All studies on the coronavirus family were dedicated to provide an overview towards an advanced statistical analysis of the collected data. The first step was a descriptive study of COVID-19 and avian corona viruses by an epidemiological comparison between the two cases. Results. All corona viruses usually tend to have relatively A-T rich DNAs which is linked to their highly A-T rich codon biases. The results indicate genetic differences between the two viruses, but the results of a percentage analysis showed that the nucleotides $\mathrm{A}+\mathrm{T}$ are both more abundant and energetically cheaper than nucleotides $\mathrm{G}+\mathrm{C}$, this gives viruses a selection advantage. Conclusion. These results give us a future positive view of this type of virus with AT-rich genomes which is selectively promoted at the host level. Recommendation. A recommendation by our study reveals that thought about the vaccine is very early but prevention has proven to be effective for this virus in chickens.

Original Article

PII: S225199392000004-10

Rec. 18 April 2020

Rev. 07 May 2020

Pub. 25 May 2020

\section{Keywords}

Avian corona virus, COVID-19,

Epidemiological

comparison,

Genomic analysis

\section{INTRODUCTION}

Coronaviruses (so called because they present a crown or corona shape) infect birds and many mammals, including humans [1] (Figure 1). The respiratory tract, gastrointestinal organs, and neurological tissues are the most common targets of coronaviruses, but other organs including the liver, heart, kidneys, and eyes may also be affected [2-4]. Epithelial cells are the primary targets of coronaviruses [5]. Widely distributed cells such as macrophages are also often infected by coronaviruses; mutation by definition late phase of the cycle during which changes in the structure of the viral particle are observed linked to the proteolysis of certain capsid proteins by a viral protease, maturation is essential for the viral particle to be infectious, coronaviruses are relatively restricted in their host spectrum, infecting only their natural host, and relatively close animal species $[6,7]$.

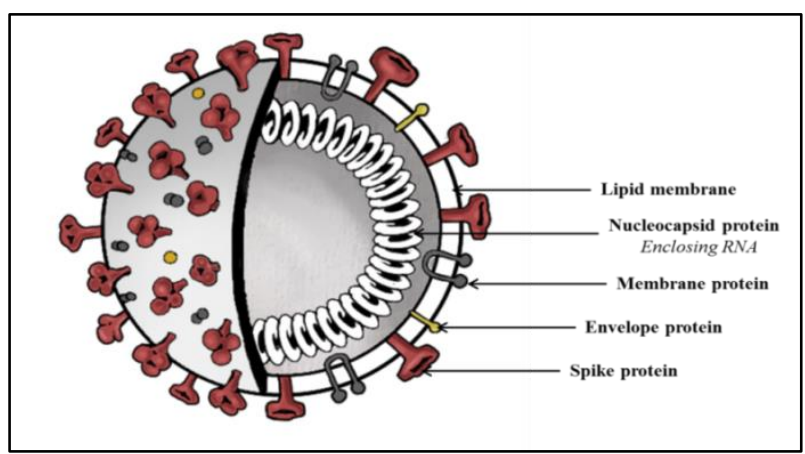

Figure 1. The Typical structure of coronavirus [16-18]

Figure 2 shows that coronavirus infection crosses the species barrier occasionally, as in the case of turkey infection with bovine coronavirus (BCoV), or experimental infection of dogs with TGEV; this may have happened with SARS (Severe Acute Respiratory Syndrome) in 2001, MERS (Middle East respiratory syndrome coronavirus) in 2012 and currently COVID-19 [8-12]. The biological vectors of the virus are poorly known and its transmission by respiratory, faecal and oral routes are common [13]. The coronavirus genome encodes a spike protein (S), an envelope protein, a membrane protein, and a nucleoprotein in this order. Among them, spike protein is the most important surface membrane protein of coronavirus [14, 15].

This study aimed to conduct a systematic review of the genetic data on COVID-19 and avian corona viruses by analyzing available information. 


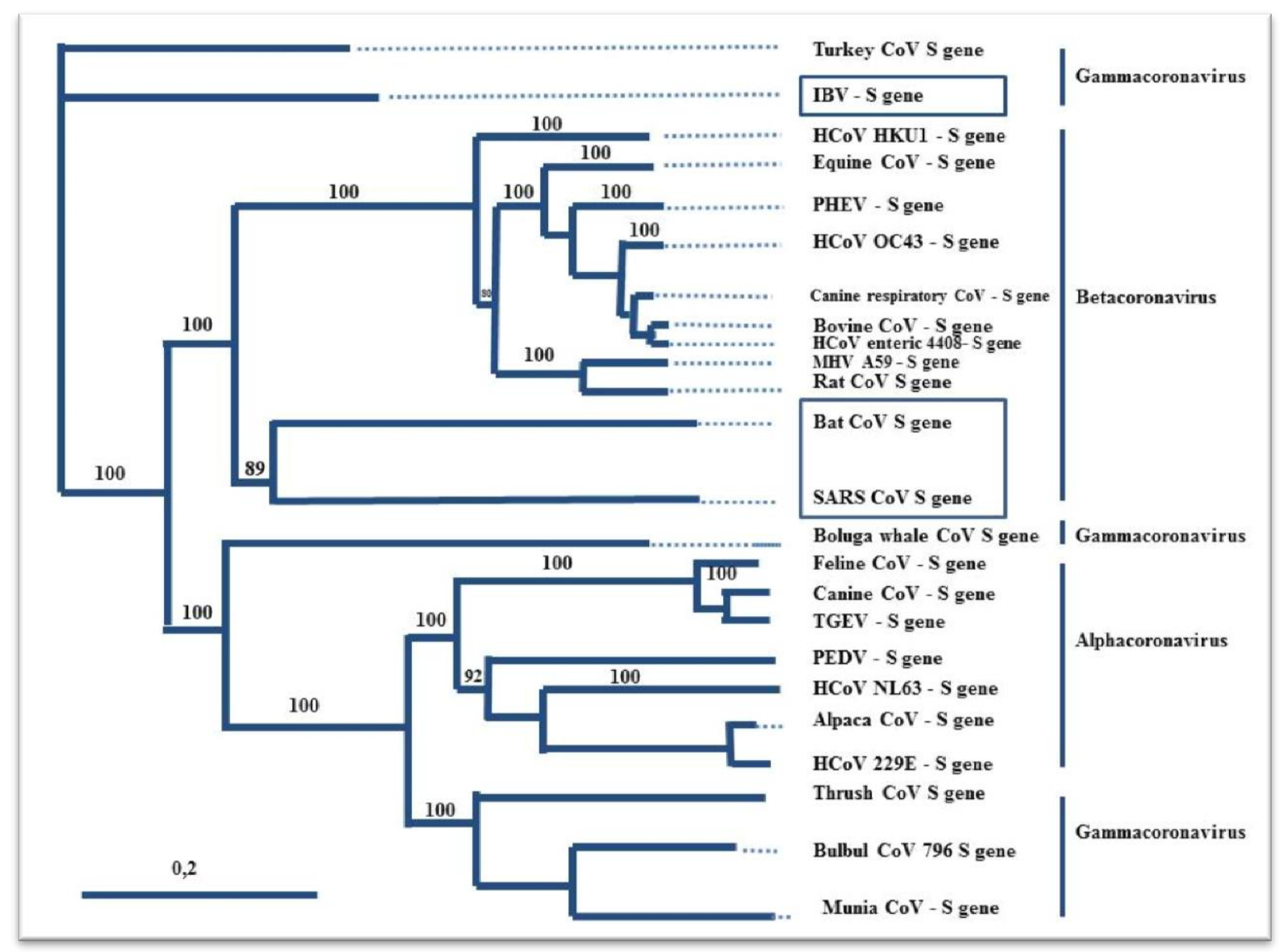

Figure 2. Phylogenetic tree analysis of the nucleocapsid genes from different coronaviruses. The alignments were performed using Clustal W, and the tree was created using a Neighbor Joining method with no outgroup (Past 2.17c).

\section{MATERIAL AND METHODS}

\section{Etiology}

The Coronaviridae belong to the order Nirovirales which includes two other viral families, the Arteriviridae and the Ronoviridae; the Coronaviridae include the genera Coronaviridae and Toroviridae [19], with the following characteristics (Table 1). Infections of humans and animals with coronaviruses appear to be ubiquitous, as evidence of infection has been obtained in all countries where serological and virological studies have been carried out $[20,21]$. According to the Baltimore classification [22, 23], coronaviruses are single-stranded viruses (unsegmented RNA+) of the 4th multiplication class (Figure 3).

Table 1. Characteristics of Coronaviridae [24-27].

\begin{tabular}{lc}
\hline Specifications & Description \\
\hline Enveloped & + \\
\hline Positive single-stranded RNA with polyA tail & + \\
\hline 5'Polymerase gene - 3' structural protein genes & + \\
\hline The incipient 3'co-terminal carries at least 4 subgenomic mRNAs. & + \\
Only the 5' region of the mRNA is translationally active. & + \\
Ribosomal reading frame shift in the polymerase gene & + \\
\hline An M protein with at least 3 membrane-crossing sequences & $27-31,5$ \\
\hline Intracellular sprouting & + \\
Genome size in kB & + \\
\hline Sequence 5' Leader & + \\
\hline Core & + \\
\hline Nucleocapsid & + \\
\hline Prominent spicules (spike) & + \\
\hline Spicules helix/propeller structure & + \\
\hline
\end{tabular}


Partially directly translated RNA and nested subgenomic RNAs

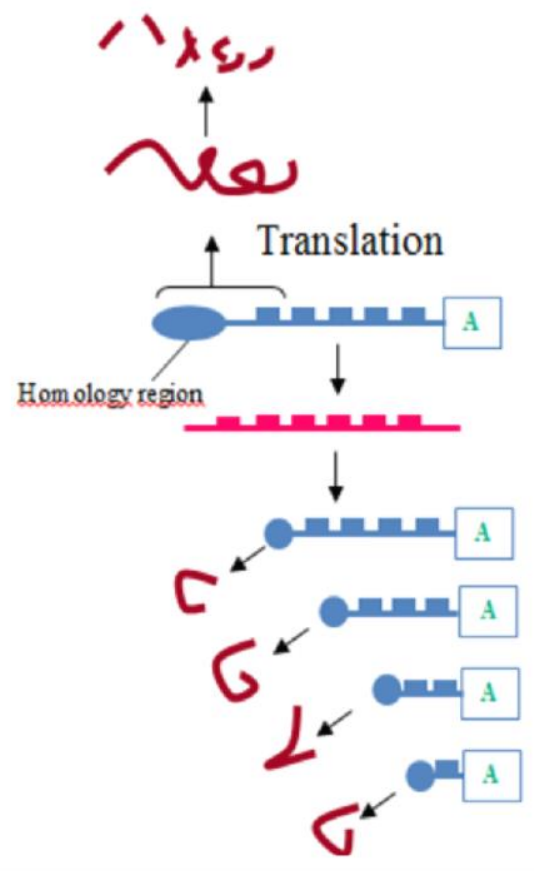

Figure 3. Multiplication of Coronavirus [28].

\section{Epidemiological comparison}

In table 2, we have summarized the difference between COVID-19 and avian corona viruses through the different epidemiological points.

Table 2. Epidemiological comparison between human and avian coronaviruses

\begin{tabular}{|c|c|c|}
\hline Comparative aspects & Avian corona virus & COVID-19 \\
\hline Epidemiology & Epidemic [29] & Pandemic [30] \\
\hline Transmission Routes & $\begin{array}{l}\text { The respiratory tract, through aerosols } \\
\text { and faeces [31] }\end{array}$ & The respiratory tract [30] \\
\hline Mode of Transmission & $\begin{array}{l}\text { Horizontal Direct and indirect; Vertical } \\
\text { direct [32] }\end{array}$ & Horizontal Direct [33] \\
\hline Incubation & $\mathbf{1 8 - 3 6}$ hours $[32]$ & $\begin{array}{l}\mathbf{2} \text { day to } \mathbf{1 4} \text { day } \\
5.2 \text { days ( } 95 \% \text { confidence interval }[\mathrm{CI}], 4.1 \text { to } \\
7.0 \text { ), with the } 95^{\text {th }} \text { percentile of the } \\
\text { distribution at } 12.5 \text { days. }[34,35]\end{array}$ \\
\hline Morbidity & $100 \%[31]$ & $\begin{array}{l}\text { WHO's estimated (on Jan. } 23,2020 \text { ) Ro to be } \\
\text { between } 1.4 \text { and } 2.5 \text {. } \\
\text { Other studies have estimated a Ro between } \\
3.6 \text { and } 4.0 \text {, and between } 2.24 \text { to } 3.58 \text {. [36] }\end{array}$ \\
\hline Mortality & $\begin{array}{l}\mathbf{2 0} \% \text { to } \mathbf{3 0} \% \text { (except for the renal tropism } \\
\text { strain) [31] }\end{array}$ & $\begin{array}{l}\text { 2\% (the elderly, Chronic diseases and } \\
\text { immunodeficiency) [36] }\end{array}$ \\
\hline Symptoms & $\begin{array}{l}\text { Signes respiratoires } \\
\text { Signes reproducteurs } \\
\text { Signes rénaux [37] }\end{array}$ & $\begin{array}{l}\text { Fever } \\
\text { Cough } \\
\text { Shortness of breath [38] }\end{array}$ \\
\hline Diagnostic & $\begin{array}{l}\text { Indirect ELISA (easy to use, but expensive), } \\
\text { Hemagglutination inhibition (applicable } \\
\text { and less expensive) and Viral neutralization } \\
\text { (more specific when it comes to serotyping). } \\
\text { [32] }\end{array}$ & RT-PCR [39] \\
\hline
\end{tabular}

Citation: Berghiche A. COVID-19 and avian corona viruses: epidemiological comparison and genetic approach. J Life Sci Biomed, 2020; 10(3): 21-28; DOI: https://dx.doi.org/10.51145/jlsb.2020.4 


\section{RESULTS AND DISCUSSION}

\section{Genetic approach; descriptive data}

The genome analysis of the complete avian infectious bronchitis virus and SARS-CoV-2 virus shows a length of 27608 and 29903 amino acids respectively. Genomic composition analysis of the two viruses show the results summarized in Table 3. The comparison of the composition of the two viruses shows that there is a remarkable difference in the numbers of adenine for the avian virus (Figure 4).

Table 3. Genomic composition of avian infectious bronchitis virus and SARS-CoV-2

\begin{tabular}{lccc}
\hline Genomic composition & SARS Cov-2 & Avian Cov & Difference \\
\hline Total count & 29903 & 27608 & 2295 \\
\hline Adenine & 8954 & 7967 & 987 \\
\hline Thymine & 9594 & 9169 & 425 \\
\hline Guanine & 5863 & 5993 & -130 \\
\hline Cytosine & 5493 & 4479 & 1014 \\
\hline
\end{tabular}

Genetic sequences are collected from the NCBI GenBank and the analysis is performed using the bio edit software [40].

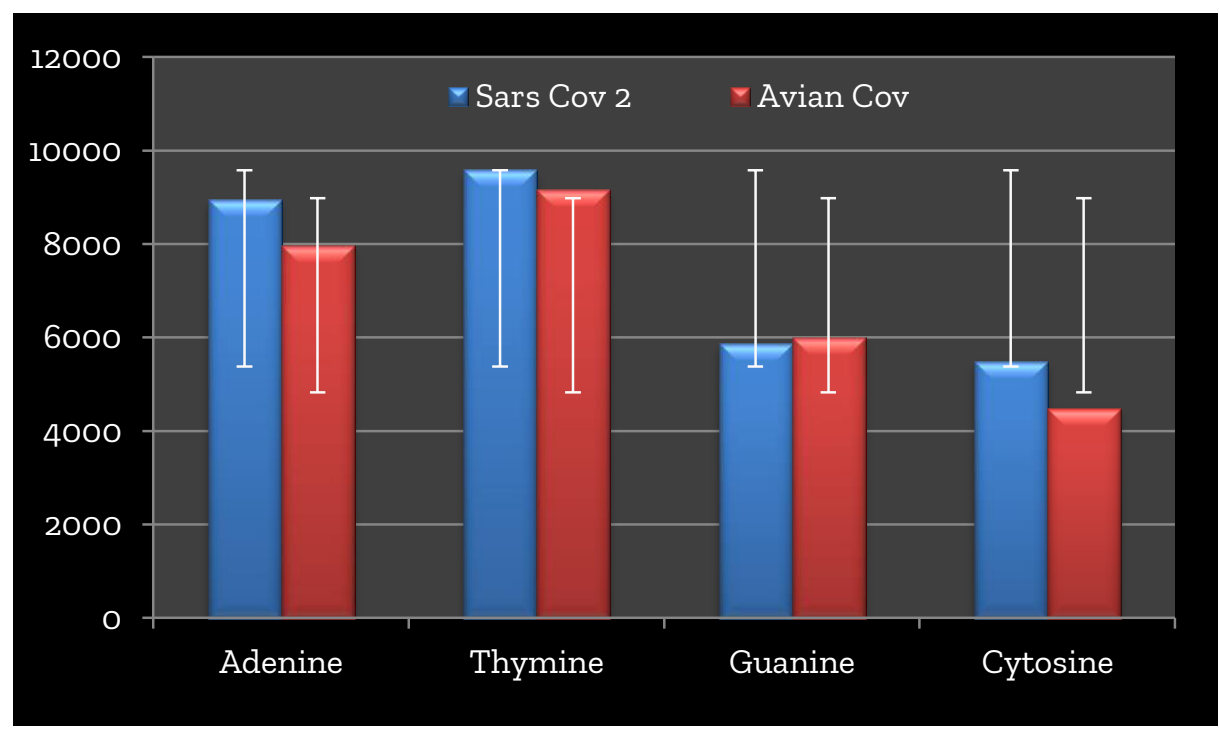

Figure 4. Comparison between the amino acid composition of Avian Infectious Bronchitis Virus and SARS-CoV-2

\section{Genetic approach: Statistical analysis}

On the basis of the results using the software Past, of the composition of the two viruses, the $F$ and $t$ test (non-parametric test) was carried out, in order to estimate the existence of a significant difference between the different components of the same virus family, and whether the amino acid level shows a variety of pathogenesis of the virus species [41]. The analysis show a signification with $F$ test which means that little difference in virus composition don't change the pathogenicity characters according to [42].

Table 4. $F$ and $t$ test Statistical table of composition

\begin{tabular}{l|c|c}
\hline Items & SARS CoV-2 & Avian Cov \\
\hline $\mathrm{N}$ & 4 & 4 \\
\hline Mean & 7476 & 6902 \\
\hline $95 \%$ & 4137.710814 & 3593.310211 \\
\hline Variance & $4.4015 E 06$ & $4.3236 E 06$ \\
\hline $95 \%$ Confidence for difference between means & -3039.9 & 4187.9 \\
\hline Bootstrapped & -1936 & 3057.3 \\
\hline F: 1.018 & p: $0.98863^{* *}$ \\
\hline t: 0.38865 & p: 0.71095 \\
\hline Welch test: unequal variance $t=0.38865$ & p: 0.71095 \\
\hline Permutation t test (N=9999): & p: 0.6524 \\
\hline
\end{tabular}




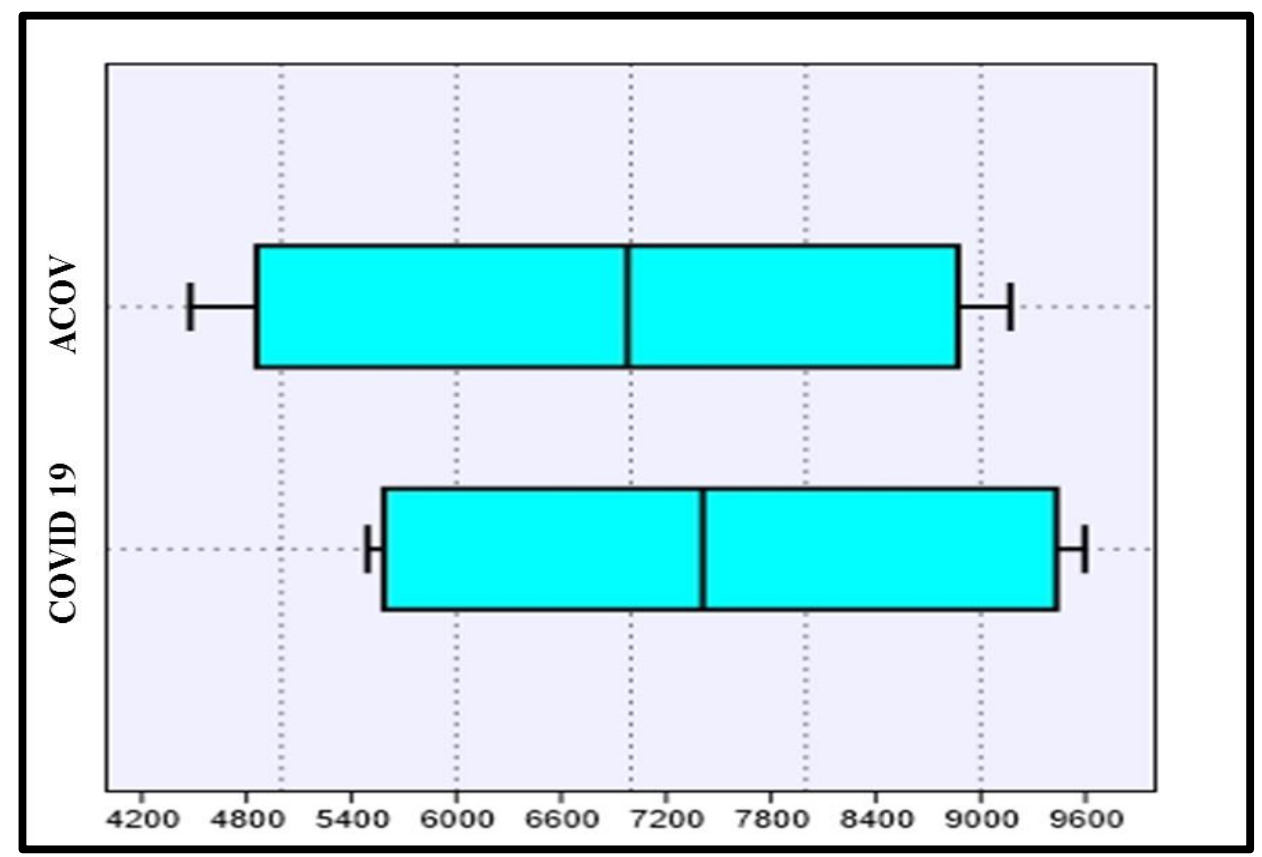

Figure 5. Box plot of Avian Infectious Bronchitis Virus and SARS-CoV-2 composition

\section{Genetic approach: Genomic data analysis}

The contents show that both viruses have a low level of $G+C$ with 37.93 and 37.97 and high level of $A+T$ with 62.068 and 62.02 respectively. Meaningfully, intracellular genetic elements that persistently or temporarily exist outside the host chromosome $[43,44]$, such as viruses, are also generally characterized by a higher AT content than their host genome [45]. The coronavirus genome is filled with A and T [46]. Since nucleotides A + T / $\mathrm{U}$ are both more abundant and less energetically expensive than nucleotides $\mathrm{G}+\mathrm{C}$, this gives viruses a selection advantage $[47,48]$. Intracellular elements, whose genome is richer in $A$ than the host genome, are selectively favoured at the host level [49].

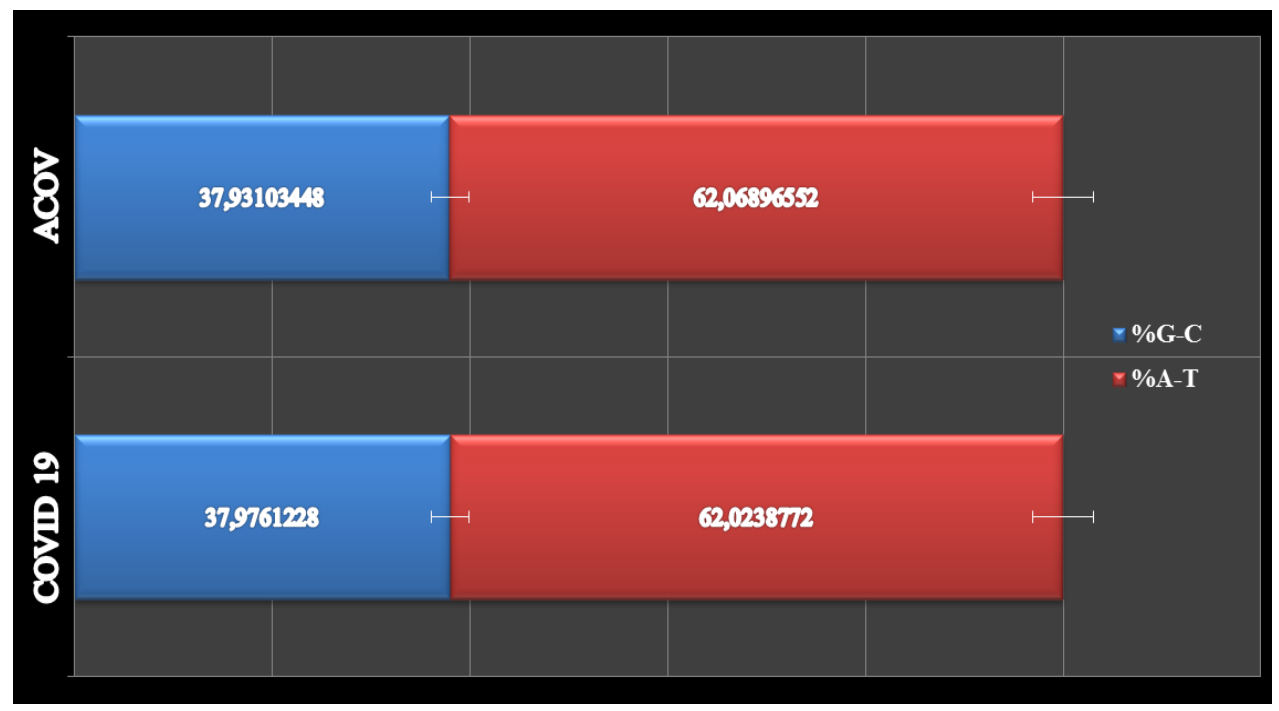

Figure 6. The Guanine+Cytosine and Adenine+Thymine contents of Avian Infectious Bronchitis Virus and SARSCoV-2

\section{CONCLUSION AND RECOMMENDATIONS}

This study gave a complete comparison of the two viruses in an epidemiological context and the exhaustive results of genomic composition contributed strongly to determine the difference between the two viruses and show their selectivity characteristics.

Based on the experience with this virus in poultry, thinking about the vaccine is a bit early because the presence of several serotypes of the virus requires the use of several valences in the same vaccine, but the prediction of the $\mathrm{A}+\mathrm{T}$ level can help in the preparation of possible vaccine ranges as in the case of the seasonal 
influenza vaccine. Also the permanent genetic mutations of this virus may lead to its weakening over time and climatic changes with the probability of increasing its mortality compared to its morbidity, and until the exact virulence profile and existing serotypes become evident. It is recommended to focus on the symptomatic treatment of secondary affections and prevention by confinement, which has proved its effectiveness as previous experience against this virus in chickens has shown its success in intensive farming known by its high population density

\section{DECLARATIONS}

\section{Acknowledgments}

To all the people who have suffered during this pandemic. To all the researchers who have published their results in order to open the chance for the researcher in the underdeveloped countries to participate in the scientific research even theoretically and specially dedicated to my friend Mister Ramy Adjailia for his help in the draw of the structural figure 1.

\section{Competing interests}

The author declares that he has no conflict of interests.

\section{REFERENCES}

1. McIntosh K, Peiris JS. Coronaviruses. InClinical Virology, Third Edition 2009 Jan 1 (pp. 1155-1171). American Society of Microbiology. DOI: $10.1128 / 9781555815981 . c h 51$

2. Anderson LJ, Schneider E. Coronaviruses. Goldman's Cecil Medicine. 2012:2102. DOI: 10.1016/B978-1-4377-1604-7.00374-2

3. Dijkman R, Jebbink MF, Koekkoek SM, Deijs M, Jónsdóttir HR, Molenkamp R, Ieven M, Goossens H, Thiel V, van der Hoek L. Isolation and characterization of current human coronavirus strains in primary human epithelial cell cultures reveal differences in target cell tropism. Journal of virology. 2013 Jun 1; 87(11):6081-90. DOI: https://doi.org/10.1128/JVI.03368-12

4. Weiss SR, Leibowitz JL. Coronavirus pathogenesis. In Advances in virus research 2011 Jan 1 (Vol. 81, pp. 85-164). Academic Press. https://doi.org/10.1016/B978-0-12-385885-6.00009-2

5. Schwegmann-Weßels C, Herrler G. Sialic acids as receptor determinants for coronaviruses. Glycoconjugate journal. 2006 Feb 1;23(12):51-8. DOI: https://doi.org/10.1007/s10719-006-5437-9

6. Calisher $\mathrm{CH}$, Childs JE, Field HE, Holmes KV, Schountz T. Bats: important reservoir hosts of emerging viruses. Clinical microbiology reviews. 2006 Jul 1;19(3):531-45. DOI: https://doi.org/10.1128/CMR.00017-06

7. Steinhauer DA, Holland JJ. Rapid evolution of RNA viruses. Annual Reviews in Microbiology. 1987 Oct; 41(1):409-31. DOI: https://doi.org/10.1146/annurev.mi.41.100187.002205; PMID: 3318675

8. Graham RL, Baric RS. Recombination, reservoirs, and the modular spike: mechanisms of coronavirus cross-species transmission. Journal of virology. 2010 Apr 1; 84(7):3134-46. DOI: https://doi.org/10.1128/JVI.01394-09

9. Hasoksuz M, Kayar A, Dodurka $T$, Ilgaz A. Detection of respiratory and enteric shedding of bovine coronaviruses in cattle in Northwestern Turkey. Acta Veterinaria Hungarica. 2005 Jan 1;53(1):137-46. DOI: https://doi.org/10.1556/avet.53.2005.1.13

10. Decaro N, Mari V, Campolo M, Lorusso A, Camero M, Elia G, Martella V, Cordioli P, Enjuanes L, Buonavoglia C. Recombinant canine coronaviruses related to transmissible gastroenteritis virus of swine are circulating in dogs. Journal of virology. 2009 Feb 1;83(3):15327. DOI: https://doi.org/10.1128/JVI.01937-08

11. de Groot RJ, Baker SC, Baric RS, Brown CS, Drosten C, Enjuanes L, Fouchier RA, Galiano M, Gorbalenya AE, Memish ZA, Perlman S. Commentary: Middle East respiratory syndrome coronavirus (MERS-CoV): announcement of the Coronavirus Study Group. Journal of virology. 2013 Jul 15;87(14):7790-2. DOI: https://doi.org/10.1128/JVI.01244-13

12. Andersen KG, Rambaut A, Lipkin WI, Holmes EC, Garry RF. The proximal origin of SARS-CoV-2. Nature medicine. 2020 Apr;26(4):4502. DOI: https://doi.org/10.1038/s41591-020-0820-9

13. Saif LJ. Animal coronaviruses: what can they teach us about the severe acute respiratory syndrome?. Revue scientifique et techniqueOffice international des épizooties. 2004 Aug 1; 23(2):643-60. DOI: https://doi.org/10.20506/rst.23.2.1513; PMID: 15702725

14. Hiscox JA, Wurm T, Wilson L, Britton P, Cavanagh D, Brooks G. The coronavirus infectious bronchitis virus nucleoprotein localizes to the nucleolus. Journal of Virology. 2001 Jan 1;75(1):506-12. DOI: https://doi.org/10.1128/JVI.75.1.506-512.2001

15. Tan YJ, Lim SG, Hong W. Characterization of viral proteins encoded by the SARS-coronavirus genome. Antiviral research. 2005 Feb 1;65(2):69-78. DOI: https://doi.org/10.1016/j.antiviral.2004.10.001

16. Graham RL, Donaldson EF, Baric RS. A decade after SARS: strategies for controlling emerging coronaviruses. Nature Reviews Microbiology. 2013 Dec; 11(12):836-48. DOI: https://doi.org/10.1038/nrmicro3143

17. Hogue BG, Machamer CE. Coronavirus structural proteins and virus assembly. InNidoviruses 2008 Jan 1 (pp. 179-200). American Society of Microbiology. DOI: 10.1128/9781555815790.ch12

18. Davies HA, Macnaughton MR. Comparison of the morphology of three coronaviruses. Archives of virology. 1979 Mar 1; 59(1-2):25-33. DOI: https://doi.org/10.1007/BF013178g1

19. Yoon KJ. 23 Overview of Viruses. 2012: 383. Google Scholar 
20. Corman VM, Eckerle I, Memish ZA, Liljander AM, Dijkman R, Jonsdottir H, Ngeiywa KJ, Kamau E, Younan M, Al Masri M, Assiri A. Link of a ubiquitous human coronavirus to dromedary camels. Proceedings of the National Academy of Sciences. 2016 Aug 30;113(35):98649. DOI: https://doi.org/10.1073/pnas.1604472113

21. Perera RA, Wang P, Gomaa MR, El-Shesheny R, Kandeil A, Bagato O, Siu LY, Shehata MM, Kayed AS, Moatasim Y, Li M. Seroepidemiology for MERS coronavirus using microneutralisation and pseudoparticle virus neutralisation assays reveal a high prevalence of antibody in dromedary camels in Egypt, June 2013. Eurosurveillance. 2013 Sep 5; 18(36):20574. DOI: https://doi.org/10.2807/1560-7917.ES2013.18.36.20574

22. Yu C, Hernandez T, Zheng H, Yau SC, Huang HH, He RL, Yang J, Yau SS. Real time classification of viruses in 12 dimensions. PloS one. 2013;8(5). DOI: 10.1371/journal.pone.0064328

23. Hulo C, De Castro E, Masson P, Bougueleret L, Bairoch A, Xenarios I, Le Mercier P. ViralZone: a knowledge resource to understand virus diversity. Nucleic acids research. 2011 Jan 1; 39(suppl_1):D576-82. DOI: https://doi.org/10.1093/nar/gkq901

24. Siddell SG, Anderson R, Cavanagh D, Fujiwara K, Klenk HD, Macnaughton MR, Pensaert M, Stohlman SA, Sturman L, Van der Zeijst BA. Coronaviridae. Intervirology. 1983; 20(4):181-9. DOI: https://doi.org/10.1159/000149390

25. Bear DA. Pasture management effects on nonpoint source pollution of Midwestern watersheds. DOI: https://doi.org/10.31274/etd180810-2769

26. Gonzalez JM, Gomez-Puertas P, Cavanagh D, Gorbalenya AE, Enjuanes L. A comparative sequence analysis to revise the current taxonomy of the family Coronaviridae. Archives of virology. 2003 Nov 1; 148(11):2207-35. DOI: https://doi.org/10.1007/s00705-003$\underline{0162-1}$

27. Basha SH. Corona virus drugs-a brief overview of past, present and future. Journal of PeerScientist. 2020; 2(2):e10oool3. Google $\underline{\text { Scholar }}$

28. Stern DF, Kennedy SI. Coronavirus multiplication strategy I. Identification and characterization of virus-specified RNA. Journal of Virology. 1980 Jun 1; 34(3):665-74. Google Scholar

29. Fellahi S, EL Harrak M, Ennaji M, Fihri OF, EL Houadfi M. Distribution épidémiologique du virus de la Bronchite infectieuse aviaire autour du monde. Revue Marocaine des Sciences Agronomiques et Vétérinaires. 2015 Mar 7; 3(2):37-42. Google Scholar

30. Lipsitch M, Swerdlow DL, Finelli L. Defining the epidemiology of Covid-19-studies needed. New England Journal of Medicine. 2020 Mar 26; 382(13):1194-6. DOI: https://doi.org/10.1056/NEJMp2002125

31. Ignjatovic J, Sapats S. Avian infectious bronchitis virus. Revue Scientifique Et Technique-Office International Des Epizooties. 2000 Aug 1; 19(2):493-501. DOI: https://doi.org/10.20506/rst.19.2.1228; PMID: 10935276

32. Cavanagh D, Naqi SA. Infectious bronchitis. Diseases of Poultry. 2003; 11:101-19. Google Scholar

33. Rothan HA, Byrareddy SN. The epidemiology and pathogenesis of coronavirus disease (COVID-19) outbreak. Journal of autoimmunity. 2020 Feb 26:102433. DOI: https://doi.org/10.1016/j.jaut.2020.102433

34. Li Q, Guan X, Wu P, Wang X, Zhou L, Tong Y, Ren R, Leung KS, Lau EH, Wong JY, Xing X. Early transmission dynamics in Wuhan, China, of novel coronavirus-infected pneumonia. New England Journal of Medicine. 2020 Jan $29.20 I$ : https://doi.org/10.1056/NEJMoa2001316

35. Zhai P, Ding Y, Wu X, Long J, Zhong Y, Li Y. The epidemiology, diagnosis and treatment of COVID-19. International Journal of Antimicrobial Agents. 2020 Mar 28:105955. DOI: doi.org/10.1016/j.ijantimicag.2020.105955

36. Wu JT, Leung K, Bushman M, Kishore N, Niehus R, de Salazar PM, Cowling BJ, Lipsitch M, Leung GM. Estimating clinical severity of COVID-19 from the transmission dynamics in Wuhan, China. Nature Medicine. 2020 Mar 19:1-5. DOI: https://doi.org/10.1016/j.ijantimicag.2020.105955

37. Picault JP, Bennejean G, Drouin P, L'Hospitalier R, Gillet JP, Guittet M, Lamande J, Le Bachelier A. Caractérisation d'une nouvelle souche de coronavirus de la bronchite infectieuse aviaire. Bulletin de l'Académie Vétérinaire de France. 1985. DOI: https://doi.org/10.4267/2042/65080

38. Surveillances V. The epidemiological characteristics of an outbreak of 2019 novel coronavirus diseases (COVID-19)-China, 2020. China CDC Weekly. 2020; 2(8):113-22. DOI: https://doi.org/10.3760/cma.j.issn.0254-6450.2020.02.003; PMID: 32064853; Google Scholar

39. Wang Y, Kang H, Liu X, Tong Z. Combination of RT-qPCR testing and clinical features for diagnosis of COVID-19 facilitates management of SARS-CoV-2 outbreak. Journal of medical virology. 2020 Feb 25. doi: https://doi.org/10.1002/jmv.25721

40. Hall T, Biosciences I, Carlsbad C. BioEdit: an important software for molecular biology. GERF Bulletin of Biosciences, 2011 Jun; 2(1):60-1. Google Scholar

41. Neumann G, Kawaoka Y. Host range restriction and pathogenicity in the context of influenza pandemic. Emerging infectious diseases. 2006 Jun;12(6):881. DOI: http://dx.doi.org/10.3201/eid1206.051336

42. Mims CA. Aspects of the pathogenesis of virus diseases. Bacteriological Reviews. 1964 Mar; 28(1):30. Google Scholar; PMID: 14127970; PMCID: PMC441209.

43. Witzany G. Natural genome-editing competences of viruses. Acta Biotheoretica. 2006 Dec 1;54(4):235-53. DOI: https://doi.org/10.1007/s10441-006-9000-7

44. Katz RA, Skalka AM. Generation of diversity in retroviruses. Annual review of genetics. 1990 Dec;24(1):409-43. DOI: https://www.annualreviews.org/doi/pdf/10.1146/annurev.ge.24.120190.002205

45. Rocha EP, Danchin A. Base composition bias might result from competition for metabolic resources. TRENDS in Genetics. 2002 Jun 1;18(6):291-4. DOI: https://doi.org/10.1016/S0168-9525(02)02690-2

46. Dutia K. A method for analysis of mutations in HIVs and SARS viruses and for homologous proteins structure characterisation. University of Massachusetts Lowell; 2005. Google Scholar

47. Walsh DP, Chang YT. Chemical genetics. Chemical reviews. 2006 Jun 14; 106(6):2476-530. DOI: https://doi.org/10.1021/cro404141

48. Stahl G, McCarty GP, Farabaugh PJ. Ribosome structure: revisiting the connection between translational accuracy and unconventional decoding. Trends in biochemical sciences. 2002 Apr 1; 27(4):178-83. DOI: https://doi.org/10.1016/S0968-0004(02)02064-9 
49. Pollard EC, Solosko W. The thermal inactivation of $\mathrm{T} 4$ and $\lambda$ bacteriophage. Biophysical journal. 1971 Jan 1; 11(1):66-74. DOI: https://doi.org/10.1016/S0006-3495(71)86195-7 